\title{
Forgotten publications by Alfred William Bennett and their effect on the nomenclature of some Asian Simaroubaceae species
}

\section{M. Turner ${ }^{1,2}$}

Summary. Attention is drawn to some forgotten papers published by Alfred William Bennett relevant to the taxonomy of Asian angiosperms. Three binomials in Simaroubaceae, were published by Bennett in a paper in the Pharmaceutical Journal and Transactions earlier than in current listings. Lectotypes are designated for Brucea mollis, Eurycoma apiculata, Picrasma javanica and P. andamanica.

Key Words. Asia, Brucea, Eurycoma, lectotypification, Picrasma.

\section{Introduction}

Alfred William Bennett (1833 - 1902) was a Victorian botanist. After a period working as a publisher, in 1868 he became lecturer in botany at Bedford College and St Thomas's Hospital in London (Cleevely 2004). Initially, he studied angiosperm groups including Burseraceae, Ochnaceae, Polygalaceae and Simaroubaceae. Bennett provided the accounts for these four families in the Flora of British India (Bennett $1872,1874,1875 \mathrm{a}, \mathrm{b}, \mathrm{c})$. As a person with a job in a medical institution, it is perhaps unsurprising that Bennett worked on the Burseraceae and Simaroubaceae; families that contain well-known medicinal plants. What seems to have been largely forgotten is that Bennett published some papers on Indian Burseraceae and Simaroubaceae around the same time as the Flora was published. There was a review of the medicinal products of the families (Bennett 1875d). This is listed in Taxonomic Literature (Stafleu \& Mennega 1993, sub no. 20.840) without a complete source. It was in fact published in the $S t$ Thomas's Hospital Reports (not St Bartholemew's as sometimes cited). Although the volume title page is dated 1874, dates of 1875 appear in various places in the text, including in pages before, as well as after Bennett's paper, so a publication date of 1875 is accepted here. The paper does not validate any names, so is not of nomenclatural importance.

Bennett also published several papers (Bennett $1873,1875 \mathrm{e}, \mathrm{f})$ on the two families in the Pharmaceutical Journal and Transactions. This was a weekly periodical making it easy to date the contributions exactly and compare these dates with the known publication dates of the parts of the Flora of British India (Stafleu \& Cowan 1979). What becomes clear is that a few species names were first validated in the Pharmaceutical Journal and Transactions rather than in the Flora of British India or elsewhere.

\section{Brucea mollis}

Wallich used this name for a plant collected in Sylhet (now in Bangladesh) and grown in the Calcutta Botanic Garden. As no description was included or referred to under number 8483 in the Numerical List (Wallich 1847), the name was not validated. The validation of the name is generally attributed to Kurz in a paper on new Burmese plants (Kurz 1873) published in the Journal of the Asiatic Society of Bengal. Fortunately, the dates of issue of the parts of this volume were printed after the contents pages. Number II, which included Kurz's paper, was issued on 28 May 1873. On 10 May 1873, Alfred Bennett's description of Brucea mollis appeared in the Pharmaceutical Journal and Transactions, and so Bennett must be taken as the publishing author of the name. A lectotype is here selected from among the material distributed by Wallich under number 8483 .

Brucea mollis Wall. ex A.W.Benn. (Bennett 1873: 882). Type: Sylhet, F. De Silva s.n. [EIC 8483 A p.p.] (lectotype K-W [K001125626], selected here, including material labelled 'b' in pencil only).

\section{Eurycoma apiculata}

Bennett's description of this species in the Flora of British India is generally taken as the original place of publication of the name. However, he included a

Accepted for publication 10 November 2020.Published online 15 March 2021

1 Singapore Botanical Liaison Officer, Royal Botanic Gardens Kew, Richmond, Surrey, TW9 3AE, UK. e-mail: i.turner@kew.org

2 Herbarium, Singapore Botanic Gardens, National Parks Board, 1 Cluny Road, Singapore, 259569, Singapore. 
description in the Pharmaceutical Journal and Transactions of 10 May 1873 nearly two years before the Simaroubaceae account was published in February 1875. A specimen collected by Maingay in Penang is here designated as lectotype for Eurycoma apiculata.

Eurycoma apiculata A.W.Benn. (Bennett 1873: 882). Type: Peninsular Malaysia, Penang, Government Hill, February 1867, A. C. Maingay 2272 [Kew distrib. no. 293] (lectotype K [K001129804], selected here).

\section{Picrasma andamanica}

The name Picrasma andamanica first appeared in print in a report on the vegetation of the Andaman Islands by Kurz (Kurz 1870) but, as no description was included or referred to, the name was not validated. The name has therefore generally been attributed to the Flora of British India in which the Simaroubaceae were published in February 1875 (Stafleu \& Cowan 1979), but a description appeared in Bennett's paper in Pharmaceutical Journal and Transactions published on 10 May 1873, so this is the first validation.

The name is now generally considered a synonym of Picrasma javanica Blume (Nooteboom 1962; Debnath 1999). Kulip \& Wong (1995) referred to the type of Picrasma javanica as an un-numbered Blume specimen collected in Java in the Leiden herbarium. There are several sheets in L that match these details, which I consider as original material for the name, but none is labelled by these authors. I therefore consider this as an ineffective lectotypification and here formally designate a sheet that has been labelled as the holotype as lectotype, to avoid further confusion. Picrasma andamanica is here lectotypified to a Kurz specimen from South Andaman in K.

Picrasma javanica Blume (1825: 248). Type: Java, C. L. Blume 248 (lectotype L [L 0850251], selected here). Picrasma andamanica Kurz ex A.W.Benn. (Bennett 1873: 882). Type: Andaman Islands, South Andaman, S. Kurz s.n. (lectotype K [K000651345], selected here).

Open Access This article is licensed under a Creative Commons Attribution 4.0 International License, which permits use, sharing, adaptation, distribution and reproduction in any medium or format, as long as you give appropriate credit to the original author(s) and the source, provide a link to the Creative Commons licence, and indicate if changes were made.
The images or other third party material in this article are included in the article's Creative Commons licence, unless indicated otherwise in a credit line to the material. If material is not included in the article's Creative Commons licence and your intended use is not permitted by statutory regulation or exceeds the permitted use, you will need to obtain permission directly from the copyright holder. To view a copy of this licence, visit http://creativecommons.org/ licenses/by/4.0/.

\section{References}

Bennett, A. W. (1872). Order XVI. Polygaleae. In: J. D. Hooker, Flora of British India, Vol. 1: 200 - 208. L. Reeve \& Co., London.

(1873). Note on Indian Simarubeae. Pharm. J. Trans., ser. 3, 3: 801 - 802, 841 - 843, 881 - 883.

(1874). Order XVI. Polygaleae. In: J. D. Hooker, Flora of British India, Vol. 1: 209 - 211. L. Reeve \& Co., London.

(1875a). Order XXXIV. Simaroubeae. In: J. D. Hooker, Flora of British India, Vol. 1: 517 - 523. L. Reeve \& Co., London.

(1875b). Order XXXV. Ochnaceae. In: J. D. Hooker, Flora of British India, Vol. 1: 523 - 527. L. Reeve \& Co., London.

- (1875c). Order XXXVI. Burseraceae. In: J. D. Hooker, Flora of British India, Vol. 1: 527 - 540. L. Reeve \& Co., London.

[A. W.] (1875d ['1874']). On the medicinal products of the Indian Simarubeae and Burseraceae. St. Thomas's Hosp. Rep., Lond., n. s., 5: $215-225$.

(1875e). Notes on Indian Burseraceae. Pharm. J. Trans., ser. 3, 6: 62 - 64, 83 - 84, $102-104$.

- (1875f). Additions and corrections to notes on Indian Simarubeae. Pharm. J. Trans., ser. 3, 6: 162.

Blume, C. L. (1825). Bijdragen tot de flora van Nederlandsch Indië, Part 5. Ter Lands Drukkerij, Batavia.

Cleevely, R. J. (2004). Bennett, Alfred William (1833 1902). In: H. C. G. Matthew \& B. Harrison (eds), Oxford Dictionary of National Biography, Vol. 5: 117 118. Oxford University Press, Oxford.

Debnath, H. S. (1999). Simaroubaceae. In: P. K. Hajra, P. S. N. Rao \& V. Mudgal (eds), Flora of Andaman $\mathcal{E}^{\circ}$ Nicobar Islands, Vol. 1: 209 - 215. Botanical Survey of India, Howrah.

Kulip, J. \& Wong, K. M. (1995). Simaroubaceae. In: E. Sopedmo \& K. M. Wong (eds), Tree Flora of Sabah and Sarawak, Vol. 1: 421 - 442. Forest Research Institute Malaysia, Kepong. 
Kurz, S. (1870). Report on the vegetation of the Andaman Islands. Office of Superintendent of Government Princting, Calcutta.

(1873). New Burmese plants. Part II. J. Asiat. Soc. Bengal, Pt. 2, Nat. Hist. 42 (2): 59 - 110.

Nooteboom, H. (1962). Simaroubaceae. In: C. G. G. J. van Steenis (ed.), Flora Malesiana, ser. I, Vol. 6: 193 226. Wolters-Noordhoff Publishing, Groningen.

Stafleu, F. A. \& Cowan, R. S. (1979). Taxonomic literature, Vol. II, H - Le. Bohn, Scheltema \& Holkema, Utrecht.
\& Mennega, E. A. (1993). Taxonomic literature, Supplement II: Be - Bo. Koeltz Scientific Books, Königstein.

Wallich, N. (1847). A numerical list of dried specimens. Nos. $8234-8521$.

\section{Publisher's Note}

Springer Nature remains neutral with regard to jurisdictional claims in published maps and institutional affiliations. 